\title{
DAMAGE POTENTIAL AND CONTROL OF THE COMMON MORMON BUTTERFLY, PAPILIO POLYTES CRAMER ON CITRUS
}

\author{
M.M.H. KHAN* AND M.N. MOLLA \\ Department of Entomology, Patuakhali Science and Technology University, \\ Dumki, Patuakhali-8602, Bangladesh
}

\begin{abstract}
Studies were conducted to know the damage potential and effect of insecticides on leaf area feeding and larval mortality of the common Mormon butterfly, Papilio polytes Cramer in the homestead garden and germplasm center of the Patuakhali Science and Technology University (PSTU) campus and in the laboratory, Department of Entomology, PSTU, Patuakhali, Bangladesh during October to December 2016. Ten Citrus host plants such as Kagoji lime-BAU-1, BAU-2, BAU-3, BAU-4, BARI kagoji, elachi lime, sweet orange, orange, jamir and pumelo were used as study materials. To determine the effects of insecticides on leaf area feeding and larval mortality, five treatments viz., $\mathrm{T}_{1}=$ Voliam flexi 300SC @ $0.5 \mathrm{ml} / \mathrm{l}$ of water, $\mathrm{T}_{2}=$ Voliam flexi 300SC @ $1.0 \mathrm{ml} / \mathrm{l}$ of water $\mathrm{T}_{3}=$ Bioneem Plus @ $0.5 \mathrm{ml} / 1$ of water, $\mathrm{T}_{4}=$ Bioneem Plus @ 1.0 $\mathrm{ml} / \mathrm{l}$ of water $\mathrm{T}_{5}=$ control were applied. Under natural field conditions, the highest percentage of leaf infestation was recorded in orange, followed by BAU-3, BAU-4, malta and elachi lime, while the lowest percentage was in BARI kagoji on 23 and 30 November, 2016. At the top canopy, the highest percentage of leaf infestation was recorded in orange and elachi $(56 \%)$, while the lowest was in BAU-4 (8\%). At the middle canopy, the highest percentage of leaf infestation was recorded in orange $(56 \%)$, while the lowest was in jambura (12\%). At the lower canopy, the highest percentage of leaf infestation was recorded in BAU-3 (40\%), while the lowest was in elachi $(8 \%)$. At the top canopy, significantly the highest percentage of infested leaves per branch was observed in orange $(51.39 \%)$ and the lowest percentage of infested leaves per branch was in BAU-4 kagoji lime (10.86\%). At middle and lower canopies, no significant difference was observed in the percentage of infested leaves per branch among different citrus varieties. The lowest percentage $(6 \%)$ of leaf area consumed by $4^{\text {th }}$ instar larva was recorded in $\mathrm{T}_{2}$ (Voliam flexi 300SC @ $1.0 \mathrm{ml} / \mathrm{l}$ of water) treated leaf, while the highest percentage of leaf area consumption was found in $\mathrm{T}_{5}$ (control) at 3 HAT. The highest percent mortality $(100 \%)$ of larvae was found in $\mathrm{T}_{2}$ treated citrus plant, while the lowest percent mortality was in the $\mathrm{T}_{3}(70 \%)$ treated plant. No mortality was recorded in the untreated control $\left(\mathrm{T}_{5}\right)$ plant.
\end{abstract}

Key words: Citrus, Damage potential, Control, Papilio polytes

*Corresponding author: <mohasin1965@pstu.ac.bd> 


\section{Introduction}

The genus Citrus is unique in its diversity of forms, and no other fruit crop can parallel it. Citrus spp. is the most cherished and highly priced fruit throughout the tropical and subtropical regions of the world (Butani 1979). The citrus industry is the third largest, in the world after mango and banana. In Bangladesh the citrus crop covering an area of about 5786 acres with an annual production of $68721 \mathrm{M}$. tons (BBS 2016). The yield of citrus in Bangladesh is very low compared to other countries due to attacks by a large number of insect pests, which cause a decline in yield (Chadha 1970). About 823 species of insects and mites attack citrus trees in the world (Ebeling 1959), around 165 species of economically important insect pests in India causing up to 30 per cent yield loss (Pruthi and Mani 1945), and 120 to 250 insect species were also reported from India (Nayar et al. 1976). The common mormon, Papilio polytes Cramer occurs throughout tropical and subtropical regions of the Old World, wide spread from the Middle East across southern Asia to Japan and Taiwan, and southward through Malaysia, Philippines, Indonesia, and New Guinea into Australia (Zakharov et al. 2004, Eastwood et al. 2006, Smith and Vane-Wright 2008, Mérit et al. 2009, Morgun and Wiemers 2012, IUCN Bangladesh 2015). These are described as the most destructive pests in the citrus nurseries in Bangladesh (Wehling et al. 2006, Shihan 2018). The New World arrival of this vagile lepidopteron pest is a potential threat to the citrus industries in these regions. The subspecies $P$. polytes is found mainly in Southeast Asia (Smith and Vane-Wright 2008) and can usually be sighted visiting flowers in the gardens of Singapore residential areas. The name of this butterfly is often derived from its food plant on which its caterpillar feeds on Citrus spp. named Key lime, Citrus aurantifolia (Tan and Khew 2012). Due to the import of kumquats (Citrus japonica) during the Chinese New Year season in Singapore, there is more food for their caterpillars to feed on (Khew 2010). The $P$. polytes is an economically important pest whose larval forms cause severe damage to the citrus family by devouring the foliage heavily during the later stages of their development. The larvae are a serious pest of citrus nursery stock (trees 1-2 ft. in height) and other young citrus trees and are capable of defoliating entire nursery groves. Larvae may utilize young foliage on more mature trees (Singh 1993, Matsumoto 1996, Narayanamma et al. 2001). The larval food plants of P. polytes in Asia are from the family Rutaceae, while in Australia and Papua New Guinea, the butterfly also feeds on host plants of the family the Fabaceae (Lewis 2010). The caterpillars feed voraciously and cause extensive damage to nurseries and young seedlings leaving behind midribs only. The caterpillars can completely defoliate young citrus trees (below 2 feet) by feeding only on fresh leaves and terminal shoots, the entire plant and devastate citrus 
nurseries, while in mature trees, caterpillars may prefer young leaves and leaf flush (Lewis, 2010; Butani 1979, Bhutani and Jotwani 1975). Severe infestation leads to retards plant growth and decreases fruit yield (Pruthi 1969). Many pesticides were tested against this pest and found effective (Shivankar 1999). Hand-picking of caterpillars and spraying with endosulfan $35 \mathrm{EC}$ ( $2 \mathrm{ml} / 10$ litres of water) were the recommended means of pest control by Indian government agencies and agricultural colleges (Unattributed 2008); however, endosulfan has since been banned by the Supreme Court of India (Economic Times 2012, Times of India 2012). Sharma and Shrivastava (1970) stated that Papilio demoleus L. is an important pest of Citrus leaves in India. In 1968 at Rewa in Madhya Pradesh, trees of $C$. reticulata were sprayed three times at intervals of 15 days with six insecticides, and treated foliage was brought into the laboratory after each application for artificial infestation with larvae of $P$. demoleus. Mortality was assessed 48,72 , and $96 \mathrm{~h}$ after infestation. The results show that a $0.2 \%$ wettable-powder spray of carbaryl was the most effective treatment, although it was not significantly superior to $0.1 \%$ gamma BHC (lindane), $0.02 \%$ endrin or $0.05 \%$ malathion; $0.03 \%$ dimethoate or phosphamidon gave comparatively poor results. So far, I know the published research report on damage potential and control strategies against the common mormon butterfly is not available in Bangladesh. Considering above facts, the research work was undertaken to know the damage potential and effect of insecticides on leaf area feeding and larval mortality of the common mormon butterfly, $P$. polytes Cramer on citrus.

\section{Materials and Methods}

Studies were conducted in the homestead garden, germplasm center, and entomology laboratory of the Patuakhali Science and Technology University (PSTU), Dumki, Patuakhali, Bangladesh, from October to December 2016.

Determination of extent of damage on citrus host plants by larvae: Data on the extent of damage were taken from 10 plants of different citrus varieties viz., Kagoji lime-BAU-1, BAU-2, BAU-3, BAU-4, BARI kagoji, elachi lime, malta, orange, jamir and Jumbura grown in the germplasm center, Department of Horticulture, PSTU. The age of the plant was 5 years. Each plant was considered one treatment replication. Five branches were selected randomly from each plant and each branch was categorized into three viz., top, middle and lower categories. The number of infested and healthy leaves was counted from each of the three categories. Then the percentage of infested leaves was estimated.

Effect of insecticides on leaf area consumption and larval mortality: For this purpose, five treatments viz., $\mathrm{T}_{1}=$ Voliam flexi 300SC @ $0.5 \mathrm{ml} / \mathrm{l}$ of water, $\mathrm{T}_{2}=$ Voliam flexi 
300SC @ 1.0 ml/l of water $\mathrm{T}_{3}=$ Bioneem Plus @ $0.5 \mathrm{ml} / \mathrm{l}$ of water, $\mathrm{T}_{4}=$ Bioneem Plus @ $1.0 \mathrm{ml} / \mathrm{l}$ of water $\mathrm{T}_{5}=$ control were used. At first, 15 lemon leaves were collected and then dipped into the solution of above mention 5 treatments. In control, treatment leaves were treated with distilled water. Each treatment replicated 3 times. Five beakers were used for preparing the solution of each treatment to avoid any admixture of the insecticides. Then the leaves were sun dried and were placed in 15 petridishes. Later on, the $4^{\text {th }}$ instar larva was individually placed in each petridish. The percent area of leaf consumed by the $4^{\text {th }}$ instar larva was determined by eye estimation at 3 HAT. The larval condition was recorded at 3 HAT due to feeding or no feeding on treated leaves. The mortality of larvae was counted at 12 HAT by applying different treatments on the citrus plant.

Statistical analysis: Data were analyzed following ANOVA using WASP (Web-based Agricultural Statistical Package) software. CD (Critical difference) means were separated by values.

\section{Results and Discussion}

Damage potential under natural field condition: The percentage of leaf infestation/plant by larvae of common mormon butterfly on different varieties of citrus on 16, 23 and 30 November, 2016 is shown in Fig. 1. On 16 November, the highest percentage of leaf infestation was recorded in elachi lime (33.91\%), followed by BAU-1 (23.08\%), orange (22.82\%), sweet orange (22.66\%), BAU-4 (21.79\%), and BAU-3 (21.79\%) while the lowest percentage was in BARI kagoji (10.64\%) followed by pumelo (12.38\%), BAU-2 $(17.54 \%)$ and jamir $(18.27 \%)$.

On 23 November, the highest percentage of leaf infestation was recorded in orange (44.00\%), followed by BAU-3 (37.33\%), sweet orange (36.00\%), elachi lime (33.33\%) and BAU-1 (29.33\%). However, the lowest percentage was in pumelo $18.67 \%$ ) followed by BAU-4 (24.00\%), BAU-2 (25.33\%), BARI kagoji (25.33\%) and jamir (26.67\%).

On 30 November, the highest percentage of leaf infestation was recorded in orange (40.00\%), followed by BAU-3 (36.00\%), BAU-4 (33.33\%), sweet orange (30.67\%) and elachi lime (30.67\%) while the lowest percentage was in BARI kagoji (17.33\%) followed by BAU-2 $(20.00 \%)$, pumelo (21.33\%), jamir $(28.00 \%)$ and. BAU-1 $(29.33 \%)$.

Percentage of leaf infestation per branch at various canopy: Fig. 2 revealed the percentage of leaf infestation per branch at a different canopy of citrus varieties. At the top canopy, the highest percentage of leaf infestation was recorded in orange and elachi 
(56\%), while the lowest was in BAU-4 (8\%). The rank order of leaf infestation from highest to lowest was orange $\geq$ elachi $>$ BAU- $3 \geq$ sweet orange $>$ BARIkagoji $\geq j$ jamir $>$ BAU1>pumelo>BAU-2>BAU-4. Likewise, at the middle canopy, the highest percentage of leaf infestation was recorded in orange (56\%) while the lowest was in pumelo (12\%). The rank order was orange $>$ sweet orange $>$ elachi $>$ BAU-2 $\geq$ BAU-4 $>$ BAU- $1 \geq$ Jamir $>$ BARIkagoji > BAU-3 > pumelo. At the lower canopy, the highest percentage of leaf infestation was recorded in BAU-3 (40\%), while the lowest was in elachi (8\%). The rank order from highest to lowest was BAU-3 > BAU-4 $\geq$ BAU-2 > BAU-1 > orange > sweetorange $\geq$ pumelo $>$ BARI kagoji $\geq$ jamir $>$ elachi.

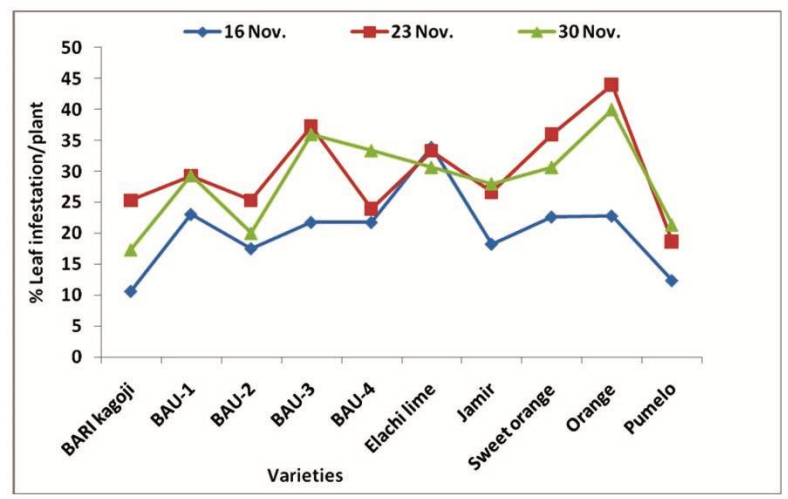

Fig. 1. Percentage of leaf infestation per plant by larvae of a common mormon butterfly on different citrus varieties on 16, 23, and 30 November, 2016.

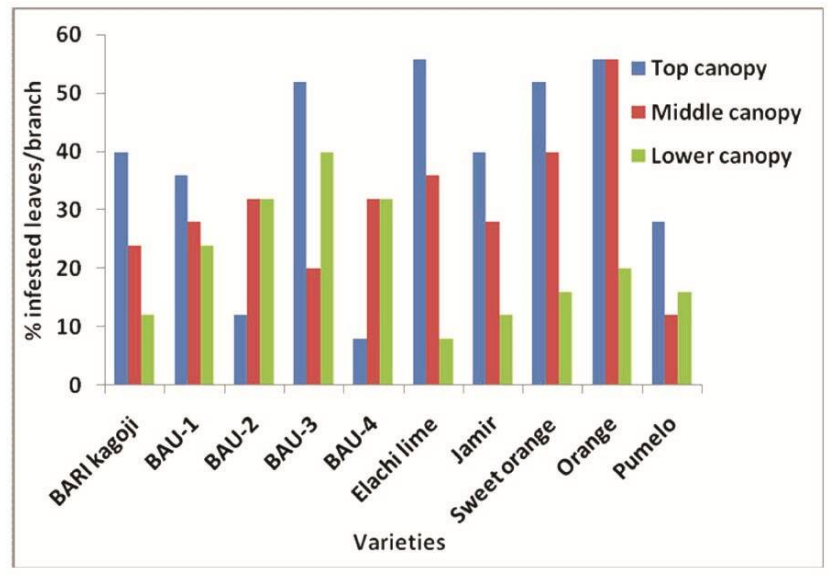

Fig. 2. Percentage of leaf infestation per branch at various canopy levels of different citurs varieties in November 2016. 
Number of infested leaves per branch per plant: At the top canopy, significantly the highest number of infested leaves/branch was recorded in elachi lime (1.79), which was statistically similar to orange (1.75), sweet orange (1.70) and BAU-3 kagoji lime followed by BARI Kagoji (1.50). However, the lowest number of infested leaves/branch was recorded in BAU-4 kagoji lime (0.91) followed by BAU-2 kagoji (0.98), Pumelo (1.33) and BAU-1 kagoji (1.46) (Table 1).

At the middle canopy, no significant difference was observed in the number of infested leaves/branches among different varieties of citrus. The range of infested leaves was 1.02 to 1.72 , while the highest number of infested leaves was on orange (1.72), and the lowest was in pumelo (1.02) (Table 1).

At the lower canopy, no significant difference was observed in the number of infested leaves/branches among different citrus varieties. The range of infested leaves was 0.91 to 1.50 while the highest number of infested leaves was recorded in BAU-3 Kagoji (1.50) followed by BAU-2 kagoji (1.38), BAU-4 (1.34) and BAU-1 kagoji (1.20) while the lowest was in Elachi lime (0.91) (Table 1, Plate 1).

Table 1. Number of infested leaves per branch per plant at different canopy level of citrus varieties

\begin{tabular}{lccc}
\hline \multirow{2}{*}{ Varieties of citrus } & \multicolumn{3}{c}{ Number of infested leaves/branch/plant at } \\
\cline { 2 - 4 } & Top canopy & Middle canopy & Lower canopy \\
\hline BARI Kagoji & $1.50^{\mathrm{ab}}$ & 1.27 & 0.98 \\
BAU-1 Kagoji & $1.46^{\mathrm{abc}}$ & 1.36 & 1.29 \\
BAU-2 Kagoji & $0.98^{\mathrm{bc}}$ & 1.40 & 1.38 \\
BAU-3 Kagoji & $1.66^{\mathrm{a}}$ & 1.19 & 1.50 \\
BAU-4 Kagoji & $0.91^{\mathrm{c}}$ & 1.44 & 1.34 \\
Elachi lime & $1.79^{\mathrm{a}}$ & 1.37 & 0.91 \\
Jamir & $1.51^{\mathrm{ab}}$ & 1.36 & 0.98 \\
Sweet orange & $1.70^{\mathrm{a}}$ & 1.55 & 1.09 \\
Orange & $1.75^{\mathrm{a}}$ & 1.72 & 1.12 \\
Pumelo & $1.33^{\mathrm{abc}}$ & 1.02 & 1.09 \\
CV (\%) & $\mathbf{3 0 . 1 6}$ & $\mathbf{2 9 . 9 0}$ & $\mathbf{3 8 . 8 5}$ \\
CD value & $\mathbf{0 . 5 6 8}$ & $\mathbf{N S}$ & $\mathbf{N S}$ \\
F value & $\mathbf{2 . 4 0 4}$ & $\mathbf{1 . 1 0 7}$ & $\mathbf{0 . 9 2 4}$ \\
Prob. & $\mathbf{0 . 0 2 9}$ & $\mathbf{0 . 3 8 8}$ & $\mathbf{0 . 5 1 8}$ \\
\hline
\end{tabular}



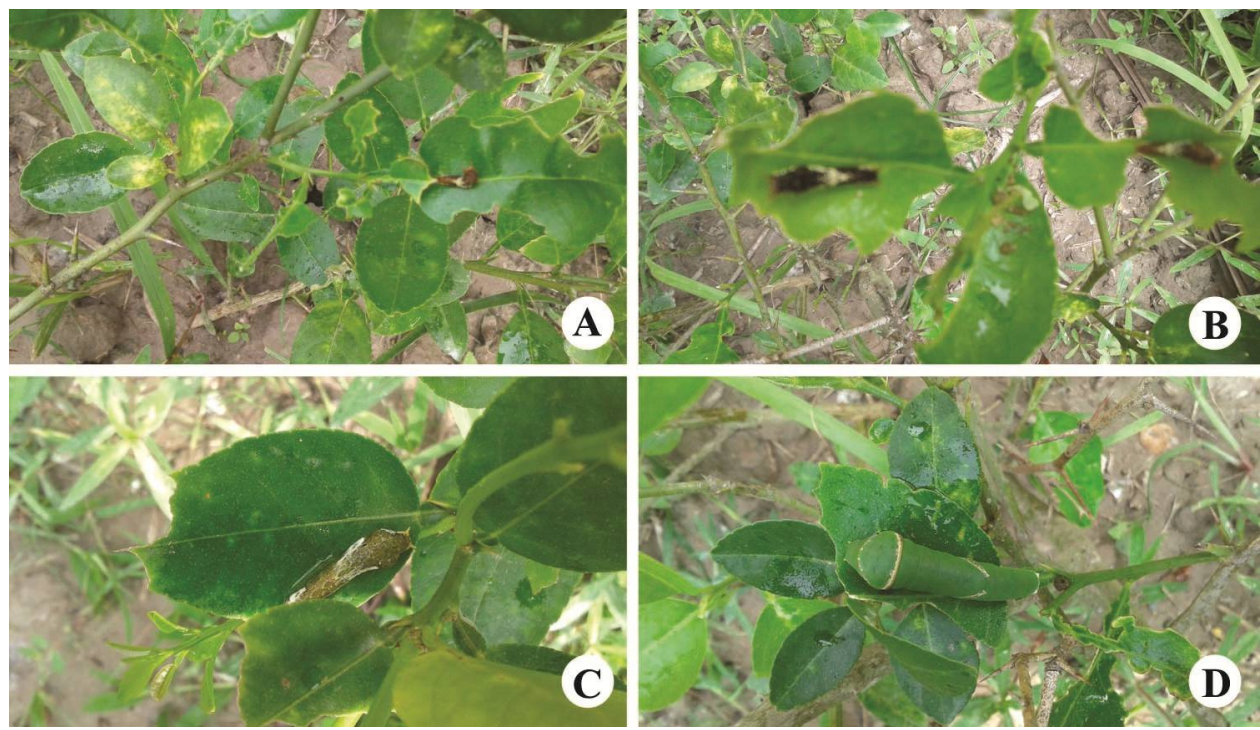

Plate 1. Damage symptom by larvae $\left(\mathrm{A}-1^{\text {st }}, \mathrm{B}-2^{\text {nd }} \& 3^{\text {rd }}, \mathrm{C}-4^{\text {th }}\right.$ and $\mathrm{D}-5^{\text {th }}$ instar $)$ of common mormon butterfly.

Percentage of infested leaves per branch per plant: The percentage of infested leaves per branch per plant of different citrus varieties at different canopy levels, is presented in Table 2. At the top canopy, significantly the highest percentage of infested leaves/branches was recorded in orange $(51.39 \%)$, which was statistically similar to sweet orange (48.85\%), elachi lime (48.69\%) and BAU-3 kagoji (42.64\%), followed by jamir (36.31\%), BARI kagoji (36.08\%), BAU-1 kagoji (33.78\%) and pumelo (28.70\%). However, the lowest percentage of infested leaves/branch was recorded in BAU-4 kagoji lime (10.86\%) followed by BAU-2 kagoji lime (13.40\%).

At the middle canopy, no significant difference was observed in the percentage of infested leaves/branches among different citrus varieties, but it ranged from $16.10 \%$ to $48.69 \%$. The highest percent leaf infestation was recorded in orange (48.69\%), followed by BAU-4 kagoji (34.17\%), BAU-1 kagoji (31.64\%), Jamir (31.41\%), BAU-2 kagoji (31.24\%) and elachi lime (30.84\%). However, the lowest percent leaf infestation was recorded in pumelo (16.10\%) followed by BAU-3 (23.86\%) and BARI kagoji (26.40\%) (Table 2).

At the lower canopy, the percentage of leaf infestation/branch ranged from $10.86 \%$ to $36.08 \%$, while the highest percent leaf infestation was recorded in BAU-3 kagoji 
(36.08\%), followed by BAU-2 Kagoji (31.24\%), BAU-1 kagoji (29.09\%) and BAU-4 kagoji $(28.55 \%)$. However, the lowest percentage of leaf infestation/branch was in elachi lime (10.86\%), followed by jamir (13.40\%), BARI kagoji (13.40\%), orange (18.24\%), sweet orange (18.63\%) and pumelo (18.63\%) (Table 2).

Table 2. Percentage of infested leaves per branch per plant at the different canopy levels of citrus varieties.

\begin{tabular}{lccc}
\hline Varieties of citrus & \multicolumn{3}{c}{ Percentage (\%) of infested leaves/branch/plant at } \\
\cline { 2 - 4 } & Top canopy & Middle canopy & Lower canopy \\
\hline BARI Kagoji & $36.08^{\text {ab }}$ & 26.40 & 13.40 \\
BAU-1 Kagoji & $33.78^{\text {ab }}$ & 31.64 & 29.09 \\
BAU-2 Kagoji & $13.40^{\mathrm{b}}$ & 31.24 & 31.24 \\
BAU-3 Kagoji & $42.64^{\mathrm{a}}$ & 23.86 & 36.08 \\
BAU-4 Kagoji & $10.86^{\mathrm{b}}$ & 34.17 & 28.55 \\
Elachi lime & $48.69^{\mathrm{a}}$ & 30.84 & 10.86 \\
Jamir & $36.31^{\mathrm{ab}}$ & 31.41 & 13.40 \\
Sweet orange & $48.85^{\mathrm{a}}$ & 38.78 & 18.63 \\
Orange & $51.39^{\mathrm{a}}$ & 48.69 & 18.24 \\
Pumelo & $28.70^{\mathrm{ab}}$ & 16.10 & 18.63 \\
CV (\%) & $\mathbf{6 0 . 5 8}$ & $\mathbf{5 9 . 1 9}$ & $\mathbf{9 2 . 7 0}$ \\
CD value & $\mathbf{2 7 . 2 5}$ & $\mathbf{N S}$ & $\mathbf{N S}$ \\
F value & $\mathbf{2 . 2 1 2}$ & $\mathbf{1 . 0 9 3}$ & $\mathbf{0 . 9 3 4}$ \\
Prob. & $\mathbf{0 . 0 4 1}$ & $\mathbf{0 . 3 9 4}$ & $\mathbf{0 . 5 1 0}$ \\
\hline
\end{tabular}

\section{Management of common mormon butterfly}

Effect of insecticides on leaf area feeding by larvae under laboratory condition: Fig. 3 revealed that the lowest percentage $(6 \%)$ of leaf area consumed by $4^{\text {th }}$ instar larva was recorded in $\mathrm{T}_{2}$ (Voliam flexi 300SC @ $1.0 \mathrm{ml} / \mathrm{l}$ of water) treated leaf followed by $\mathrm{T}_{4}$ (Bioneem Plus @ $1.0 \mathrm{ml} / \mathrm{l}$ of water), $\mathrm{T}_{1}$ (Voliam flexi 300SC @ $0.5 \mathrm{ml} / \mathrm{l}$ of water), and $\mathrm{T}_{3}$ (Bioneem Plus @ $0.5 \mathrm{ml} / \mathrm{l}$ of water) while the highest percentage of leaf area consumption was found in $\mathrm{T}_{5}$ (control) at $3 \mathrm{HAT}$. After 3 hours, all the larvae were found dead.

Effect of different treatment on the larval mortality of common mormon butterfly on a treated citrus plant: It was evident from figure 4 that the highest percent mortality 
(100\%) of larvae was found in $\mathrm{T}_{2}$ treated citrus plant followed by $\mathrm{T}_{4}(90 \%)$ and $\mathrm{T}_{1}(80 \%)$. In comparisons, the lowest percent mortality was in $\mathrm{T}_{3}(70 \%)$ treated plant. No mortality was recorded in the untreated control $\left(\mathrm{T}_{1}\right)$ plant.

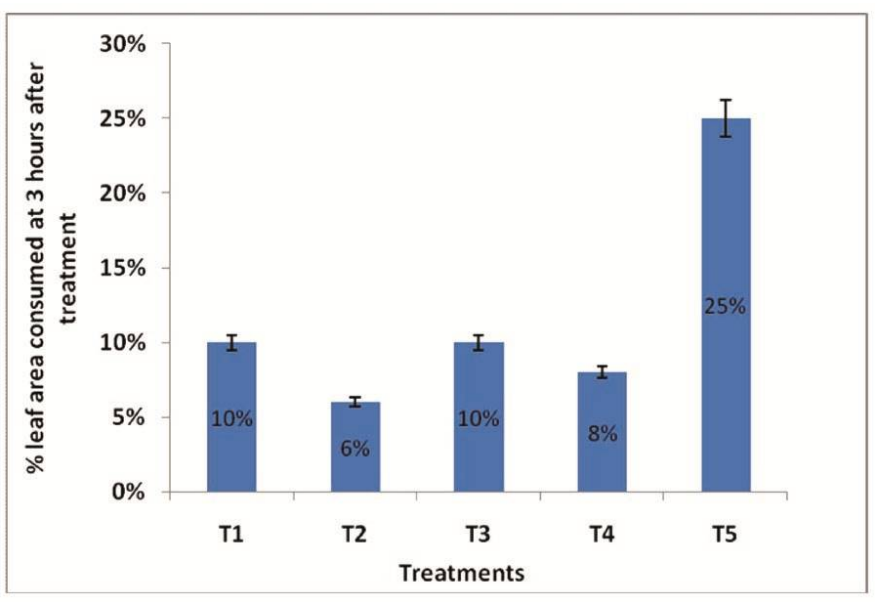

Fig. 3. Effectiveness of different treatments on leaf area consumed by $4^{\text {th }}$ instar larva at 3 HAT. $T_{1}=$ Voliam flexi $300 \mathrm{SC} @ 0.5 \mathrm{ml} / \mathrm{l}$ of water, $\mathrm{T}_{2}=$ Voliam flexi $300 \mathrm{SC} @ 1.0 \mathrm{ml} / \mathrm{l}$ of water, $\mathrm{T}_{3}=$ Bioneem Plus 1\% EC @ $0.5 \mathrm{ml} / \mathrm{l}$ of water, $\mathrm{T}_{4}=$ Bioneem Plus 1\% EC @ $1.0 \mathrm{ml} / \mathrm{l}$ of water, $\mathrm{T}_{5}=$ Control.

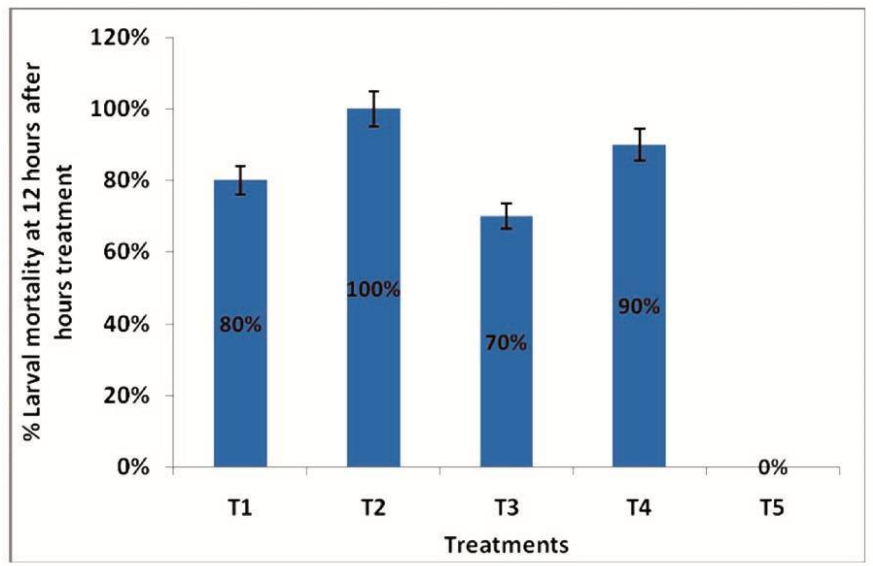

Fig. 4. Effectiveness of different treatments on the larval mortality of common mormon butterfly at $12 \mathrm{HAT}$ on citrus plant. $\mathrm{T}_{1}=$ Voliam flexi $300 \mathrm{SC} @ 0.5 \mathrm{ml} / \mathrm{l}$ of water, $\mathrm{T}_{2}=$ Voliam flexi $300 \mathrm{SC} @ 1.0 \mathrm{ml} / \mathrm{l}$ of water, $\mathrm{T}_{3}=$ Bioneem Plus $1 \% \mathrm{EC} @ 0.5 \mathrm{ml} / \mathrm{l}$ of water, $\mathrm{T}_{4}=$ Bioneem Plus 1\% EC @ $1.0 \mathrm{ml} / \mathrm{l}$ of water, $\mathrm{T}_{5}=$ Control. 
This finding shows that the percentage of leaf infestation varied among three canopies of citrus varieties. The highest and lowest percentage of leaf infestation for various citrus varieties differed from one canopy to another. It was also observed that the larval stage of the pest caused damage by feeding voraciously on tender leaves and terminal shoots. As a habit, they feed on the margin reaching the midrib. The grown-up larvae even fed on mature leaves and completely defoliated the nurseries. The damage was more predominant in the nursery than in orchard trees. The habit of the larva and nature of damage found in the present study conformed with observations of Atwal (1964), Butani (1973). Sarada et al. (2014) stated that the larval population density was high during October to December months and July to December was the most favorable period of its activity in general. Severe infestation results in defoliation of the tree due to feeding of pedicels, heavily infested plants bear no fruit (Bhutani and Jotwani 1975) and leads to retards plant growth and decreases fruit yield (Pruthi 1969). The phytophagous larvae generally eat younger leaves and can denude growing shoots. During major infestations, the entire plant may be defoliated (Zacher 1914). The lemon butterfly larvae feeding on young leaves throughout the larval period and the population of lemon butterflies was higher in August and lowest in May. The extent of damage was also found higher in August (Shikdar et al. 2008). Narayanamma and Savithri (2002) found leaf infestation ranged from $14.71 \%$ to $59.98 \%$ by $P$. demoleus. In this study, the insecticide voliam flexi 300 SC @ $1.0 \mathrm{ml} / 1$ of water was found effective on larval mortality of the common mormon butterfly. This result is supported by Shivankar (1999), who stated that many pesticides were tested against this pest and found effective. Spraying with aqueous extract of neem seed kernal @ $0.5 \%$ twice at 8 days interval is effectively checked the pest population as it has strong antifeedant and repellant activity (Singh et al. 1996, Chauke et al. 1999) who stated azadirachtin $(0.3 \%)$ as effective one against citrus butterfly among the various neem products. The efficacy of different concentrations of the biopesticides Bacillus thuringiensis and Beauveria bassiana, as well as of neem seed

kernel extract, neem oil and azadirachtin were tested by Narayanamma and Savithri (2002) against $P$. demoleus in Andhra Pradesh, India.

\section{References}

Atwal, A.S. 1964. Insect pests of citrus in the Punjab-Biology and control of citrus caterpillar Papilio demoleus L. (Lepidoptera: Papilionidae). Punjab Hort. J. 4(1): 40-44.

BBS. 2016. Bangladesh Bureau of Statistics, Yearbook of Agricultural Statistics-2015, $27^{\text {th }}$ Series, Statistics and Information Division, Ministry of Planning, Government of the People's Republic of Bangladesh.

Butani, D.K. 1973. Insect pests of fruit crops- citrus. Pesticides 7(12): 23-26. 
Butani, D.K. and M.G. Jotwani. 1975. Trends in the control of insect pests of fruit crops in India. Pesticides Mannual. pp.139-149.

Butani, D.K. 1979. Insects and fruits. Indian Agriculturul Research Institute, New Delhi. India.

Chadha, K.L. 1970. Rootstocks in citrus decline in India-causes and control (Chadha, K. L., Randhawa, N. S., Bindra, G. S., Chohan, J. S. and Knoor, L. C. eds.) A joint publication of Punjab Agril. University, Ohio State University and USAID. pp. 9-25.

Chauke, R.P., A.N. Pasalwas and S.R. Dalal. 1999. Efficacy of various insecticides and plant products against the larvae of lemon butterfly (Papilio demoleus). Hi-tech citrus management: Proceedings of International Symposium on citriculture (Nov. 23-27) held at NRC for citrus, Nagpur. pp. 928-930.

Eastwood, R., S.L. Boyce and B.D. Farrell. 2006. The provenance of Old World swallowtail butterflies, Papilio demoleus (Lepidoptera: Papilionidae), recently discovered in the New World. Ann. Entomol. Soc. Am. 99: 164-168.

Ebeling, W. 1959. Sub-tropical Fruits Pests. University of California Press, Los Angeles. pp. 287.

IUCN Bangladesh. 2015. Red List of Bangladesh. Vol. 7: Butterflies. IUCN, International Union for Conservation of Nature, Bangladesh Country Office, Dhaka, Bangladesh. pp. 400.

Khew, S.K. 2010. A Field Guide to the Butterflies of Singapore. Singapore: Ink On Paper Communications Pte Ltd.

Lewis, D.S. 2010. Lime Swallowtail, Chequered Swallowtail, Citrus Swallowtail Papilio demoleus Linnaeus (Insecta: Lipidoptera: Papilionidae) (PDF). University of Florida (IFAS Extension). Retrieved 26 November 2010.

Matsumoto, K. 1996. Establishment of Papilio demoleus L. (Papilionidae) in Java. J. Lepid. Soc. 50: $139-140$.

Mérit, X., J.-M. Gayman, V. Mérit and L. Manil. 2009. Papilio demoleus [Linnaeus, 1758] - une expansion mondiale (Lepidoptera: Papilionidae). Lépidoptères - Revue des Lépidoptéristes de France 18: 44-47.

Morgun, D.V. and M. Wiemers. 2012. First record of the Lime Swallowtail Papilio demoleus Linnaeus, 1758 (Lepidoptera, Papilionidae) in Europe. Journal of Research on the Lepidoptera 45:85-89.

Narayanamma, V.L., P. Savithri and R. Rao. 2001. Influence of citrus butterfly Papilio demoleus L. damage on growth parameters of the sweet orange host plant. Indian J. Plant Prot. 29: 140-141.

Narayanamma, V.L. and P. Savithri. 2002. Seasonal abundance of citrus butterfly, Papilio demoleus Linn. on Sathgudi sweet orange and tenali acid lime. J. Appl. Zool. Res. 13(1): 54-56.

Nayar, K.K., B.V. Ananthakrishnan and B.V. David. 1976. General and Applied Entomology. TATA McGraw Hill Publishing Co. Ltd. New Delhi. pp. 486.

Pruthi, H. and M.S. Mani. 1945. Our knowledge of the insects and mite pests of citrus in India and their control. Imperial Council of Agril. Research Science. Monograph 16: 42.

Pruthi, H. 1969. Text book of Agriculturla Entomology. Ind.Council of Agril. Res., New Delhi pp. 634.

Sarada, G., K. Gopal, K.T. Venkata Ramana, L. Mukunda Lakshmi and T. Nagalakshmi. 2014. Citrus Butterfly (Papilio demoleus Linnaeus) Bioiogy and Management: A Review. J. Agric. and Allied Sci. 3(1): 17-25.

Sharma, R. P. and O. S. Shrivastava. 1970. Studies on the chemical control of Papilio demoleus Linn, on Citrus reticulata. Madras Agric. J. 57(5): 300-302.

Shihan, T. S. 2018. Records of new larval host plants of some common butterflies of Bangladesh. Journal of Threaten Taxa. 10(2): 11303-11311. 
Shikdar, H., M.P. Ali, M. Asaduzzaman, A.A. Mamun and M. Ahmad. 2008. Seasonal abundance and nature of damage of citrus pests on five varieties of citrus. Bangladesh j. entomol. 18(2): 61-68.

Shivankar, V.J. 1999. Recent trends in insect pest management of citrus. Hi-tech citrus management: Proceedings of International Symposium on citriculture (Nov. 23-27) held at NRC for citrus, Nagpur. pp.773-774.

Singh, S.P. 1993. Species composition and diapause in citrus butterflies. J. Insect Sci. 6: 48-52.

Singh, R., R. Mahalakshmi and S.N. Vijayachandran. 1996. The lemon butterfly : Potential pest of Aegle marmelos Corr. in nursery and its management with neem. Insect Environ. 2(3): 70.

Smith, C.R. and R.I. Vane-Wright. 2008. Classification, nomenclature and identification of lime swallowtail butterflies: A post-cladistic analysis (Lepidoptera: Papilionidae). Systematics and Biodiversity 6(2): 175-203.

"Supreme Court bans Endosulfan for eight weeks - Economic Times". Articles. economictimes. indiatimes. com. 13 May 2011. Retrieved 20 March 2012. Alt webcitation url.

"Supreme Court refuses to lift ban on endosulfan - Times Of India". Articles. timesofindia. indiatimes.com. 5 August 2011. Retrieved 20 March 2012. Alt webcitation url

Tan, H. and S.K. Khew 2012. Caterpillars of Singapore's Butterflies. Singapore: National Parks Board

Unattributed (2008). Acid Lime (Citrus aurantifolia (Christm) Swingle)". TNAU Agritech Portal Horticulture:Fruit Crops: Acid Lime. Tamil Nadu Agricultural University. Retrieved 20 March 2012. Alt webcitation url.

Wehling, W., C.A. Nunez and J. Glass berg. 2006. Lime swallowtails in a New World. American Butterflies. pp. 31-34.

Zacher, F. 1914. Papilios als Schädlinge der Agrumen. Entomologische Zeitschrift, Frankfurt am Main 27(50): 288-289.

Zakharov, E., C.R. Smith, D.C. Lees, A. Cameron, R.I. Vane-Wright and F.A. Sperling. 2004. Independent gene phylogenies and morphology demonstrate a Malagasay [sic] origin for a wide-ranging group of swallowtail butterflies. Evolution 58:2763-2782.

(Revised copy received on 07.04.2021) 